\title{
Correction to: How do Consumers Reconcile Positive and Negative CSR-Related Information to Form an Ethical Brand Perception? A Mixed Method Inquiry
}

Katja H. Brunk ${ }^{1}$. Cara de Boer ${ }^{2}$

Published online: 3 February 2020

(c) Springer Nature B.V. 2020

\section{Correction to:}

Journal of Business Ethics (2020) 161:443-458

https://doi.org/10.1007/s10551-018-3973-4

This article is incorrectly classified as Review Paper in the online and print publication. The correct classification for this article is Original Paper. The publisher apologizes for the inconvenience caused.

Publisher's Note Springer Nature remains neutral with regard to jurisdictional claims in published maps and institutional affiliations.

The original article can be found online at https://doi.org/10.1007/ s10551-018-3973-4.

Katja H. Brunk

Brunk@Europa-uni.de

Cara de Boer

Cara.deBoer@kuleuven.be

1 Center for Market Communications, Europa-Universität Viadrina, Große Scharrnstr. 59, 15230 Frankfurt (O),

Germany

2 KU Leuven, Naamsestraat 22, 3000 Leuven, Belgium 